\title{
Preparation of Lignocellulose-Based
} Activated Carbon Paper as a Manganese Dioxide Carrier for Adsorption and in-situ Catalytic
Degradation of Formaldehyde

\author{
Xiao Zhang ${ }^{1}$, Chunhui Zhang ${ }^{2 *}$, Qixuan Lin ${ }^{1}$, Banggui Cheng ${ }^{1}$, Xinxin Liu ${ }^{1}$, Feng Peng ${ }^{3}$ \\ and Junli Ren ${ }^{1 *}$ \\ ${ }^{1}$ State Key Laboratory of Pulp and Paper Engineering, South China University of Technology, Guangzhou, China, ${ }^{2}$ School of \\ Light Industry and Engineering, South China University of Technology, Guangzhou, China, ${ }^{3}$ College of Materials Science and \\ Technology, Institute of Biomass Chemistry and Technology, Beijing Forestry University, Beijing, China
}

\section{OPEN ACCESS}

Edited by:

Kangle $L v$,

South-Central University for

Nationalities, China

Reviewed by:

Zhihua Xu,

Jianghan University, China Jinlong Wang

Wuhan University of

Technology, China

*Correspondence:

Chunhui Zhang

chunhui@scut.edu.cn

Junli Ren

renjunli@scut.edu.cn

Specialty section This article was submitted to Catalysis and Photocatalysis,

a section of the journal

Frontiers in Chemistry

Received: 26 September 2019 Accepted: 08 November 2019 Published: 09 December 2019

Citation:

Zhang $X$, Zhang $C$, Lin $Q$, Cheng $B$, Liu X, Peng F and Ren J (2019) Preparation of Lignocellulose-Based Activated Carbon Paper as a Manganese Dioxide Carrier for Adsorption and in-situ Catalytic Degradation of Formaldehyde.

Front. Chem. 7:808

doi: 10.3389/fchem.2019.00808
Formaldehyde is a colorless, highly toxic, and flammable gas that is harmful to human health. Recently, many efforts have been devoted to the application of activated carbon to absorb formaldehyde. In this work, lignocellulose-based activated carbon fiber paper (LACFP) loaded with manganese dioxide $\left(\mathrm{MnO}_{2}\right)$ was fabricated for the adsorption and in-situ catalytic degradation of formaldehyde. LACFP was prepared by two-stage carbonization and activation of sisal hemp pulp-formed paper and was then impregnated with manganese sulfate $\left(\mathrm{MnSO}_{4}\right)$ and potassium permanganate $\left(\mathrm{KMnO}_{4}\right)$ solutions; $\mathrm{MnO}_{2}$ then formed by in situ growth on the LACFP base by calcination. The catalytic performance of $\mathrm{MnO}_{2}$-loaded LACFP for formaldehyde was then investigated. It was found that the suitable carbonization conditions were elevating the temperature first by raising it at $10^{\circ} \mathrm{C} / \mathrm{min}$ from room temperature to $280^{\circ} \mathrm{C}$, then at $2^{\circ} \mathrm{C} / \mathrm{min}$ from 280 to $400^{\circ} \mathrm{C}$, maintaining the temperature at $400^{\circ} \mathrm{C}$ for $1 \mathrm{~h}$, and then increasing it quickly from 400 to $700^{\circ} \mathrm{C}$ at $15^{\circ} \mathrm{C} / \mathrm{min}$. The conditions used for activation were similar to those for carbonization, with the temperature additionally being held at $700^{\circ} \mathrm{C}$ for $2 \mathrm{~h}$. The conditions mentioned above were optimized to maintain the fiber structure and shape integrity of the paper, being conducive to loading with catalytically active substances. Regarding the catalytic activity of $\mathrm{MnO}_{2}$-loaded LACFP, the concentration of formaldehyde decreased by $59 \pm 6 \mathrm{ppm}$ and the concentration of $\Delta \mathrm{CO}_{2}$ increased by $75 \pm 3 \mathrm{ppm}$ when the reaction proceeded at room temperature for $10 \mathrm{~h}$. The results indicated that $\mathrm{MnO}_{2}$-loaded LACFP could catalyze formaldehyde into non-toxic substances.

Keywords: lignocellulose biomass, carbon fiber paper, manganese dioxide, catalytic degradation, formaldehyde

\section{INTRODUCTION}

With the increasing development of the world economy, environmental problems are becoming more and more serious all over the world. Among pollution sources, volatile organic compounds (VOCs) are harmful atmospheric pollutants for human and animals (Zhu et al., 2019). Of these VOCs, formaldehyde, due to its chronic toxicity and extensive sources, has become one of the most 
pervasive air pollutants (Nie et al., 2016). Formaldehyde is also included in a list of carcinogens published by the International Agency for Research on Cancer (Salthammer, 2013). Therefore, the removal of formaldehyde is necessary for human health.

Catalytic oxidation has been proved to be a useful method for degrading formaldehyde. It mainly includes photocatalytic oxidation (Sun et al., 2010; Dou et al., 2019), plasma technology (Saulich and Müller, 2013; Lo et al., 2015), thermal catalytic oxidation (Liu et al., 2019), and room-temperature catalysis (Wang et al., 2015). However, both photocatalytic oxidation and thermal catalytic oxidation use large-scale equipment, such as a heating unit and a light source. Furthermore, plasma technology requires the use of plasma instruments. These facilities occupy a large amount of space and are high-cost. Thus, many researchers have focused on the catalytic oxidation of formaldehyde at room temperature. There are two main catalytic materials for the catalytic oxidation of formaldehyde at ambient temperature, namely noble metals, such as Pt (Cui et al., 2015; Wang L. et al., 2017), Pd (Huang and Leung, 2011; Tan et al., 2015), Au (Hong et al., 2016; Ma et al., 2016), and Ag (Lu et al., 2018), and non-noble metal oxides, such as $\mathrm{MnO}_{2}$ (Dai et al., 2016; Rong et al., 2018), $\mathrm{CuO}$ (Jin et al., 2013; Pei et al., 2015), and $\mathrm{TiO}_{2}$ (Zeng et al., 2014). Among non-noble metal oxides, $\mathrm{MnO}_{2}$ is considered to be an excellent catalyst for the catalytic degradation of formaldehyde.

Activated carbon fiber (ACF) is used to adsorb formaldehyde because of its large specific surface area, abundant micropores, and excellent adsorption capacity (Gopinath and Kadirvelu, 2018; Puziy et al., 2018). However, formaldehyde-adsorbed ACF could cause secondary pollution of the environment. Furthermore, as present, the common precursors used in the preparation of ACF are pitch (Dai et al., 2016), polyacrylonitriles (Lee et al., 2013), and phenolic compounds (An et al., 2009), which originate from fossil fuels. In contrast, biomass-based carbon materials have gained widespread attention because of their abundance, renewability, superior recyclability, and environmental properties. Many efforts have also been devoted to determining how to improve the adsorption capacity of biomassbased carbon materials for formaldehyde (Boonamnuayvitaya et al., 2005; Kumagai et al., 2008; Abdul Manap et al., 2018). For example, Boonamnuayvitaya et al. (2005) prepared activated carbons from coffee residues using the different activators of zinc chloride, nitrogen, carbon dioxide, and steam, of which preparation with zinc chloride showed the highest capacity for formaldehyde adsorption. Kumagai et al. (2008) prepared carbons and activated carbons to remove formaldehyde by using rice husks and found that the activated carbon demonstrated higher adsorption capacity than the carbon preparation. However, secondary pollution is still a challenge (how to treat the formaldehyde-adsorbed biomass-based carbon materials). Therefore, it is important to develop new technologies for the removal of formaldehyde by adsorption and in situ catalysis using biomass-based carbon materials loaded with noble metals or metal oxides, which will be favorable to environmental protection.

Herein, lignocellulose-based activated carbon fiber paper (LACFP) loaded with $\mathrm{MnO}_{2}$ was fabricated to adsorb formaldehyde and then used for in-situ $\mathrm{MnO}_{2}$-loaded catalysis to degrade formaldehyde at room temperature. LACFP was prepared by two-stage carbonization and activation of sisal hemp pulp-formed paper so as to obtain a long fiber structure and maintain the shape integrity of the paper. $\mathrm{MnO}_{2}$ was then formed by in situ growth in the internal structure of the LACFP and on the surfaces of fibers by the impregnation of LACFP with solutions of manganese sulfate $\left(\mathrm{MnSO}_{4}\right)$ and potassium permanganate $\left(\mathrm{KMnO}_{4}\right)$ in turn. LACFP and $\mathrm{MnO}_{2}-$ loaded LACFP were characterized by thermogravimetry (TG), Fourier transform infrared spectroscopy (FTIR), scanning electron microscopy (SEM), energy dispersion spectrum (EDS), transmitting electron microscopy (TEM), Brunauer-EmmettTeller (BET), X-ray photoelectron spectroscopy (XPS), and $\mathrm{X}$-ray diffraction (XRD). In addition, the catalytic performance of $\mathrm{MnO}_{2}$-loaded LACFP for the degradation of formaldehyde was investigated.

\section{EXPERIMENTAL SECTION}

\section{Materials}

Pulp board of unbleached sisal hemp was obtained from Zhuzhou Times New Material Technology Co., Ltd, and the contents of cellulose, hemicellulose, and lignin were measured, which were $64.0,17.7$, and $7.0 \mathrm{wt} \%$, respectively. Potassium hydroxide (KOH, AR) was purchased from Guangzhou Chemical Reagent Factory. Potassium permanganate $\left(\mathrm{KMnO}_{4}, \mathrm{AR}\right)$ was purchased from Shantou Guanghua Chemical Factory Co., Ltd. Manganese sulfate $\left(\mathrm{MnSO}_{4}, \mathrm{AR}\right)$ was purchased from Shanghai Macklin Biochemical Co., Ltd. Formaldehyde (HCHO, AR) solution containing 37\% formaldehyde was bought from Hubei Aosheng New Material Technology Co. Ltd. These chemicals were used as received without further purification.

\section{Preparation of LACFP}

The sisal hemp pulp board (dried pulp: $2.8 \mathrm{~g}$ ) was split into pieces, impregnated in water for $48 \mathrm{~h}$ and then highly dispersed at a stirring speed of $6,000 \mathrm{r} / \mathrm{min}$. Subsequently, the dispersed pulp was used to form the paper sheet (quantitation: $140 \mathrm{~g} / \mathrm{m}^{2}$ ) using papermaking equipment. The paper sheet was cut into small rectangular pieces of paper (length $100 \mathrm{~mm}$, width $50 \mathrm{~mm}$ ). The paper sample was placed in a stainless steel horizontal tubular furnace (length $900 \mathrm{~mm}$, interior diameter $800 \mathrm{~mm}$ ) and carbonized through a certain heating procedure in a nitrogen atmosphere. Importantly, the carbonation was carried out in several stages according to the TGA result for the sisal hemp pulp-based paper. After the carbonation reaction was over, the sample was impregnated with a given concentration of $\mathrm{KOH}$ solution for $12 \mathrm{~h}$. The impregnated sample was then dried at $105^{\circ} \mathrm{C}$ for $5 \mathrm{~h}$. The activation conditions were the same as with the carbonization mentioned above, but the holding time at the activation temperature was increased to $2 \mathrm{~h}$. LACFP was formed and washed with hot ultrapure water several times, then dried in an oven at $105^{\circ} \mathrm{C}$ for $5 \mathrm{~h}$.

\section{Loading of LACFP With $\mathrm{MnO}_{2}$}

$\mathrm{MnO}_{2}$ was formed by in-situ growth in LACFP. $151 \mathrm{mg}$ of $\mathrm{MnSO}_{4}$ and $105 \mathrm{mg}$ of $\mathrm{KMnO}_{4}$ were dissolved in $50 \mathrm{ml}$ of ultrapure water and stirred for $1 \mathrm{~h}$, respectively. LACFP was 
immersed in the $\mathrm{MnSO}_{4}$ solution for $12 \mathrm{~h}$. It was then taken out, and the $\mathrm{KMnO}_{4}$ solution was added dropwise into the sample with power ultrasound for $30 \mathrm{~min}$. Subsequently, the $\mathrm{KMnO}_{4}$ solution including the LACFP was reacted at $90^{\circ} \mathrm{C}$ for $5 \mathrm{~h}$. The sample was dried at $105^{\circ} \mathrm{C}$ for $5 \mathrm{~h}$ and was calcined at $280^{\circ} \mathrm{C}$ for $2 \mathrm{~h}$. Consequently, $\mathrm{MnO}_{2}$-loaded LACFP was formed.

\section{Characterization}

TG (TAQ500, America) was used to analyze the thermal behavior of sisal hemp pulp-based paper under a nitrogen atmosphere at a specific flow. The first heating procedure was set from 20 to $800^{\circ} \mathrm{C}$ at a rate of $10^{\circ} \mathrm{C} / \mathrm{min}$. The FTIR spectrum was recorded with a VERTEX 70 spectrometer (Bruker, Germany). SEM (ZEISS, Germany), with an EDS detector, was used to examine the morphological structure of the LACFP and $\mathrm{MnO}_{2}$ loaded LACFP and to determine the chemical compositions of $\mathrm{MnO}_{2}$-loaded LACFP. The nitrogen adsorption-desorption isotherms were obtained with a TriStar II 3flex (Micromeritics Instrument, USA) at $77 \mathrm{~K}$. The XRD (Bruker, Germany) patterns of the LACFP and $\mathrm{MnO}_{2}$-loaded LACFP were obtained on a Bruker diffractometer with $\mathrm{Cu} \mathrm{K} \alpha$ radiation. XPS (Kratos Axis Ulra DLD) was used to analyze the chemical state of $\mathrm{Mn}$ in the sample.

\section{Catalytic Performance of $\mathrm{MnO}_{2}$-Loaded LACFP}

Catalytic degradation of formaldehyde using $\mathrm{MnO}_{2}$-loaded LACFP was performed in a sealed glass reactor. $\mathrm{MnO}_{2}$-loaded LACFP (100 mg) was placed in a petri dish and settled in the reactor. The formaldehyde solution $(10 \mu \mathrm{L})$ was injected into another petri dish, which was also placed in the reactor. The detectors for $\mathrm{CO}_{2}$ and formaldehyde were placed in this sealed glass bottle, respectively. After the sample, formaldehyde solution, and detectors had been placed in the glass bottle, the adsorption and degradation reaction of formaldehyde started, and the detectors began to detect the concentrations of formaldehyde and $\mathrm{CO}_{2}$. The time of every experiment was controlled to $10 \mathrm{~h}$. Meanwhile, a comparative study was carried out using no catalyst and LACFP $(100 \mathrm{mg})$. A portable formaldehyde alarm detector (PGD3-C- $\mathrm{CH}_{2} \mathrm{O}$ ) and portable $\mathrm{CO}_{2}$ alarm detector (PGD3-C- $\mathrm{CO}_{2}$ ), which were purchased from Shenzhen Xinss Technology Development Co., Ltd, were used to test the concentrations of gaseous $\mathrm{HCHO}$ and $\mathrm{CO}_{2}$, respectively. The catalytic performance of the sample was evaluated by analyzing the increase in the $\Delta \mathrm{CO}_{2}$ concentration and the decrease in the formaldehyde concentration. Figure 1 depicts a schematic diagram of the device for catalytic degradation reaction of formaldehyde using $\mathrm{MnO}_{2}$-loaded LACFP.

\section{RESULTS AND DISCUSSION}

\section{Analysis of Carbonization Conditions}

TG and differential thermogravimetry (DTG) curves of sisal hemp pulp-based paper are shown in Figure 2A. The heating procedure was set as going from 20 to $700^{\circ} \mathrm{C}$ at a heating rate of $10^{\circ} \mathrm{C} / \mathrm{min}$. Three main weight loss stages could be observed,

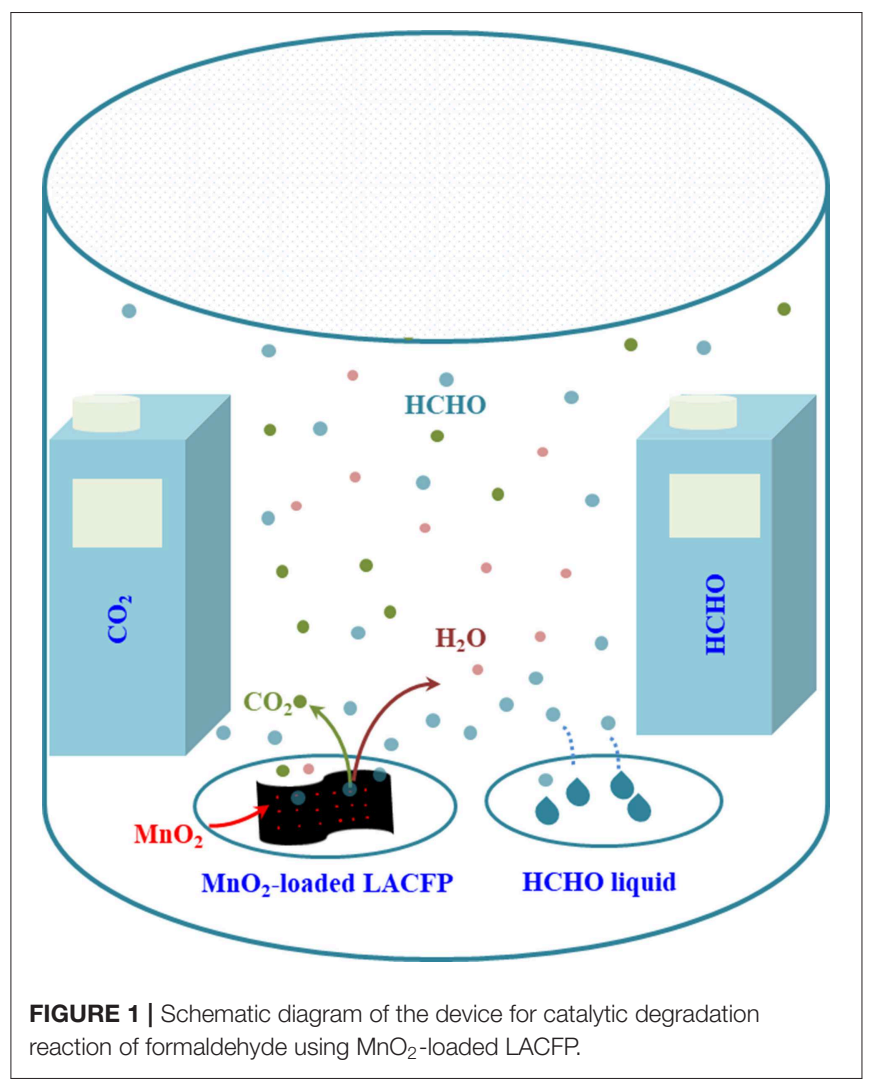

which occurred in the temperature ranges of room temperature$280^{\circ} \mathrm{C}, 280-400^{\circ} \mathrm{C}$, and $400-700^{\circ} \mathrm{C}$, respectively. In this study, sisal hemp pulp was applied as the raw material, in which most lignin and pectin were removed by cooking technology, and there was $64.0 \mathrm{wt} \%$ cellulose, $17.7 \mathrm{wt} \%$ hemicellulose, and 7.0 $\mathrm{wt} \%$ lignin. Compared to cellulose and lignin, hemicellulose had relatively lower thermal stability. In the TGA of hemicellulose, cellulose, and lignin, the main weight loss of hemicellulose mainly occurred at $220-315^{\circ} \mathrm{C}$ (Yang et al., 2007), and the main pyrolysis temperature of cellulose was in the range from 315 to $400^{\circ} \mathrm{C}$ (Yan Y. et al., 2018), whereas, compared with hemicellulose and cellulose, lignin had high thermal stability and could be decomposed from 400 to $500^{\circ} \mathrm{C}$ (Arias et al., 2006; Ishak et al., 2011; Chen et al., 2019). For Figure 2A, considering the content of the components of sisal hemp pulp and thermal stability of the three main components, the content of hemicellulose in the sisal hemp pulp-based paper was only $17.6 \%$, so analysis of the DTG shows no large mass loss from room temperature to $280^{\circ} \mathrm{C}$. The pyrolysis occurring from room temperature to $280^{\circ} \mathrm{C}$ mainly included decomposition of hemicellulose and removal of physically adsorbed water. A sharp mass loss step occurred beginning at $280^{\circ} \mathrm{C}$ and ending at $400^{\circ} \mathrm{C}$, with a maximum weight loss rate at $350^{\circ} \mathrm{C}$, caused by the decomposition of cellulose in the high-cellulose-content sisal hemp pulp-based paper. After $400^{\circ} \mathrm{C}$, the curves of TG and DTG both reached a balanced state, and there was no obvious mass loss. Furthermore, the band at $3,332 \mathrm{~cm}^{-1}$ in the FTIR spectra in Figure 3 was 

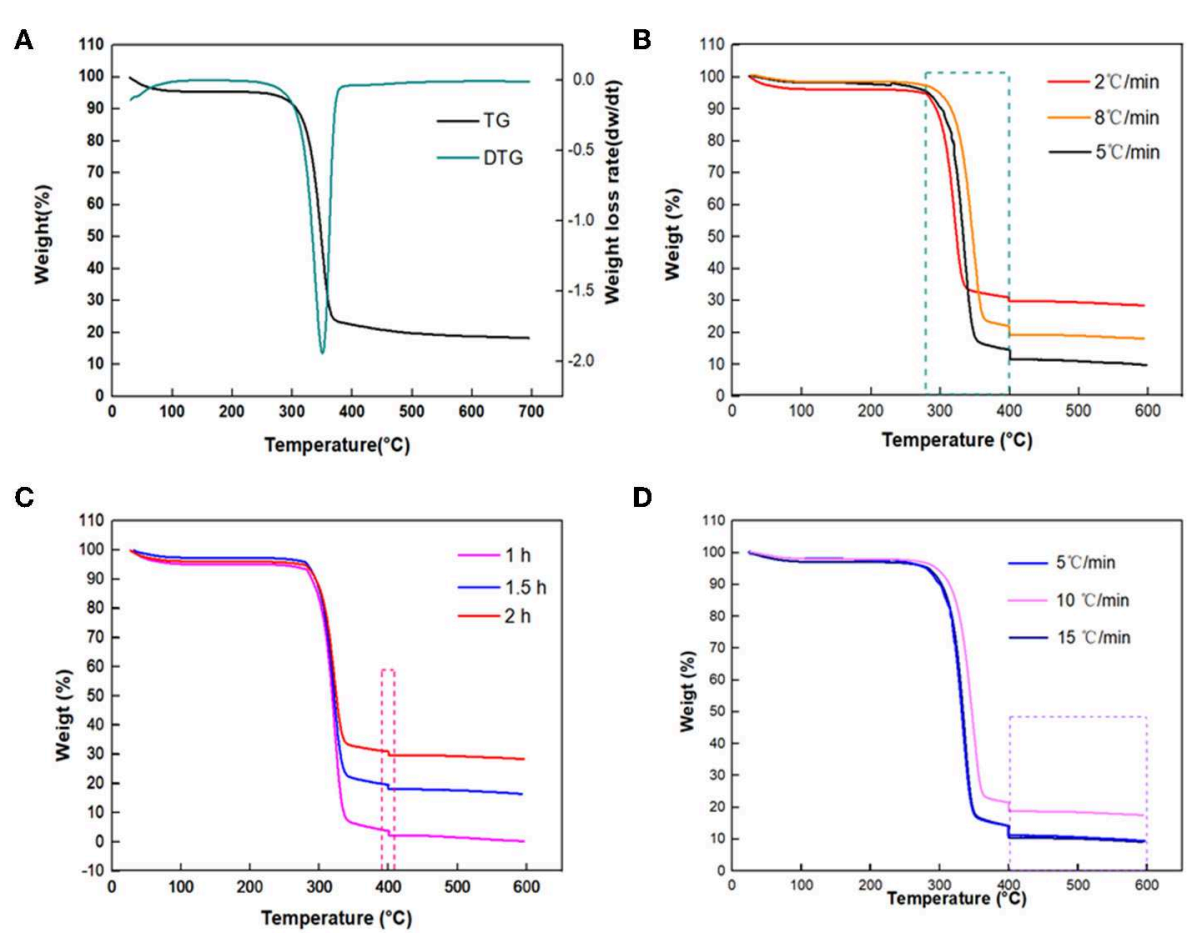

D

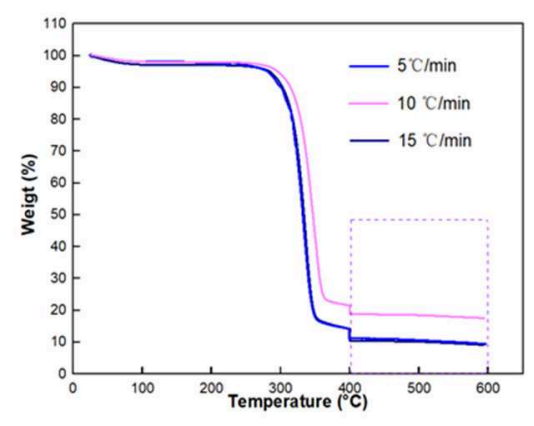

FIGURE 2 | TG and DTG curves of sisal hemp pulp-based paper (A); TG curves at $280-400^{\circ} \mathrm{C}$ at different heating rates $\left(8,5\right.$, and $\left.2^{\circ} \mathrm{C} / \mathrm{min}\right)(\mathbf{B})$; at $400^{\circ} \mathrm{C}$ with different holding times $(1,1.5$, and $2 \mathrm{~h})$ (C); and at $400-600^{\circ} \mathrm{C}$ at different heating rates $\left(5,10\right.$, and $\left.15^{\circ} \mathrm{C} / \mathrm{min}\right)$ (D).

attributed to $\mathrm{O}-\mathrm{H}$ stretch and that at $2,909 \mathrm{~cm}^{-1}$ to the stretch of $-\mathrm{CH}_{3}$ (Deng et al., 2016). The absorbance at $1,636 \mathrm{~cm}^{-1}$ characterizes the absorbed water (Peng and $\mathrm{Wu}, 2010$ ). The band at $1,516 \mathrm{~cm}^{-1}$ was attributed to skeletal vibrations of lignin (Cheng et al., 2018). The characteristic absorption peaks of cellulose and hemicellulose were at 1,157, 1,103, 1,024, and $893 \mathrm{~cm}^{-1}$ (Peng and Wu, 2010; Liang et al., 2018). However, it was observed that the characteristic absorption peaks of cellulose and hemicellulose declined and the peaks of lignin basically disappeared after carbonization. According to the results mentioned above, attention should be paid to the heating rate between 280 and $400^{\circ} \mathrm{C}$ (corresponding to a large mass loss) to optimize the carbonization conditions for obtaining high yields of carbon fibers. Some of the literature has also indicated that the heating rate and holding time both influenced the morphology and structure of the sample (Sangmanee and Maensiri, 2009; Pan et al., 2011). In this work, different heating rates of 8,5 , and $2{ }^{\circ} \mathrm{C} / \mathrm{min}$ for carbonization temperatures from 280 to $400^{\circ} \mathrm{C}$ were comparatively investigated to minimize the mass loss of sisal hemp pulp-based paper as much as possible and maintain fiber length and pore structure.

Figure 2B and Table 1 show that when the heating rates were 8,5 , and $2^{\circ} \mathrm{C} / \mathrm{min}$, the corresponding mass losses at $280-400^{\circ} \mathrm{C}$ were $75.33,81.15$, and $63.50 \%$, respectively, which indicated that the mass loss between 280 and $400^{\circ} \mathrm{C}$ was mainly through the decomposition of most of the cellulose. A heating rate of $2^{\circ} \mathrm{C} / \mathrm{min}$ resulted in the lowest mass loss of the different heating rates. In general, a high heating rate caused larger mass loss and more

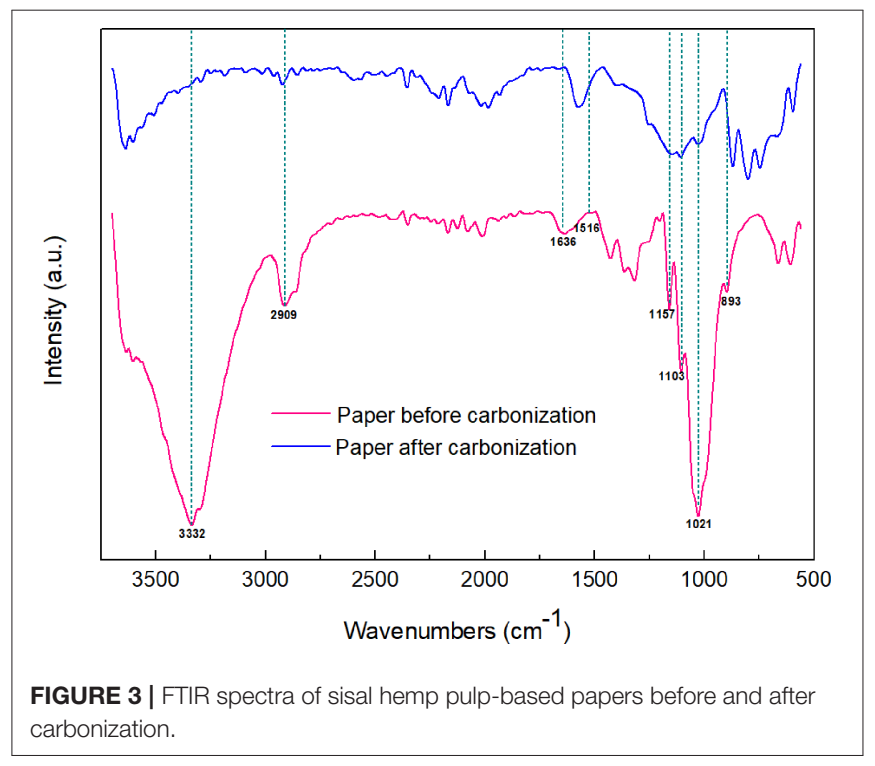

severe damage to the fiber. Accordingly, $2^{\circ} \mathrm{C} / \mathrm{min}$ is the most desirable heating rate to obtain a high yield of carbon fibers.

Herein, the influence of the holding time on the mass loss was also studied; the results are shown in Figure 2C and Table 2. When the holding times were $1.0,1.5$, and $2.0 \mathrm{~h}$, the mass losses at $400^{\circ} \mathrm{C}$ were $1.475,1.490$, and $1.250 \%$, respectively, implying a 
slight difference. To reduce cost and energy consumption for the preparation of carbon fiber, the suitable condition was deemed to be holding at $400^{\circ} \mathrm{C}$ for $1.0 \mathrm{~h}$.

In addition, the effects of heating rates on the mass loss of sisal hemp pulp-based paper between 400 and $600^{\circ} \mathrm{C}$ at different

TABLE 1 | Mass losses of sisal hemp pulp-based paper at $280-400^{\circ} \mathrm{C}$ at different heating rates $\left(8,5\right.$, and $\left.2^{\circ} \mathrm{C} / \mathrm{min}\right)$.

\begin{tabular}{ll}
\hline Heating rate $\left({ }^{\circ} \mathbf{C} / \mathbf{m i n}\right)$ & Mass loss (\%) \\
\hline 8 & 75.33 \\
5 & 81.15 \\
2 & 63.50 \\
\hline
\end{tabular}

TABLE 2 | Mass losses of sisal hemp pulp-based paper at $400^{\circ} \mathrm{C}$ with different holding times (1.0, 1.5, and 2.0 h)

\begin{tabular}{lc}
\hline Holding time $(\mathbf{h})$ & Mass loss $(\%)$ \\
\hline 1.0 & 1.475 \\
1.5 & 1.490 \\
2.0 & 1.250 \\
\hline
\end{tabular}

TABLE 3 | Mass losses of sisal hemp pulp-based paper at $400-600^{\circ} \mathrm{C}$ at different heating rates $\left(5,10\right.$, and $\left.15^{\circ} \mathrm{C} / \mathrm{min}\right)$.

\begin{tabular}{lc}
\hline Heating rate $\left({ }^{\circ} \mathbf{C} / \mathbf{m i n}\right)$ & Mass loss $(\%)$ \\
\hline 5 & 1.77 \\
10 & 1.24 \\
15 & 1.20
\end{tabular}

heating rates were also investigated, as shown in Figure 2D and Table 3. When the heating rates were 5,10 , and $15^{\circ} \mathrm{C} / \mathrm{min}$, the mass losses in the temperature range of $400-600^{\circ} \mathrm{C}$ were 1.77 , 1.24 , and $1.20 \%$, respectively, indicative of a slight difference. This result was consistent with the above TGA in Figure 2A, indicating that the sisal hemp pulp-based paper contained less lignin. Therefore, $15^{\circ} \mathrm{C} / \mathrm{min}$ was used as the heating rate from 400 to $600^{\circ} \mathrm{C}$ for rapid heating.

The surface morphology of carbonized sisal hemp pulpbased paper is shown in Figure 4. When the carbonization temperature rose to 800 and $900^{\circ} \mathrm{C}$, the structure of the carbon fiber was severely damaged, especially at $900^{\circ} \mathrm{C}$ (Figures 4A,B). When the carbonization temperature was $700^{\circ} \mathrm{C}$, fibers retained their complete structure (Figure 4C), and the cell lumen of the fibers was retained (Figure 4D), which were conducive to preparing adsorbent materials and use as catalyst material carriers. Consequently, the final carbonization temperature used was $700^{\circ} \mathrm{C}$. According to the results of TGA, FTIR, and SEM above, the optimal carbonization was conducted as follows: a heating rate of $10^{\circ} \mathrm{C} / \mathrm{min}$ from ambient temperature to $280^{\circ} \mathrm{C}$, then at $2^{\circ} \mathrm{C} / \mathrm{min}$ between 280 and $400^{\circ} \mathrm{C}$, a holding time of $1 \mathrm{~h}$ at $400^{\circ} \mathrm{C}$, and then heating at $15^{\circ} \mathrm{C} / \mathrm{min}$ from 400 to $700^{\circ} \mathrm{C}$. Photographs of the sisal hemp pulp-based paper before and after carbonization are shown in Figure 5. After carbonization, the area of the paper shank to $52.1 \%$ of the original, and the color became black (Figures 5A,B).

\section{Analysis of Activation Conditions}

In order to increase the specific surface area and enhance the adsorption capacity, sisal hemp pulp-carbon paper was
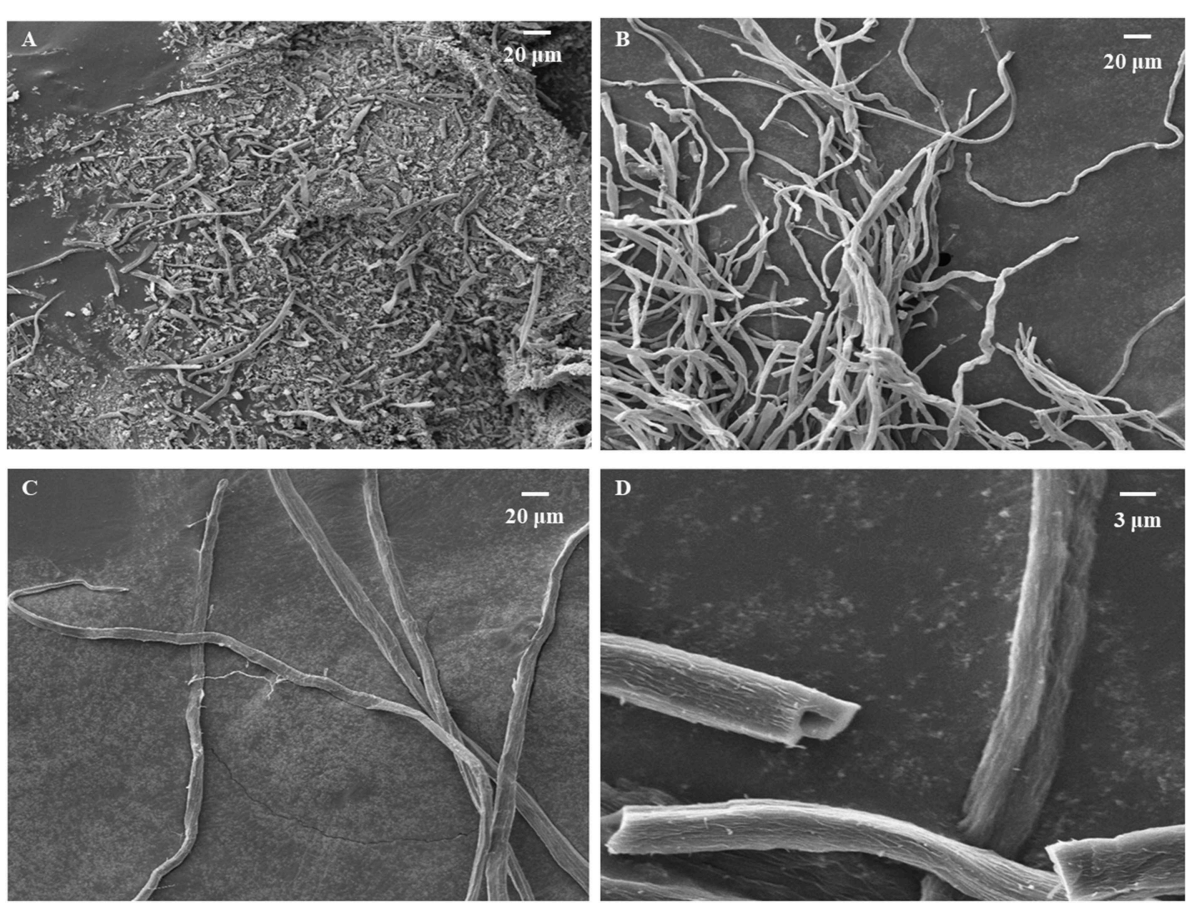

FIGURE 4 | SEM images of carbonized sisal hemp pulp-based paper at $900^{\circ} \mathrm{C}$ (A), $800^{\circ} \mathrm{C}$ (B), and $700^{\circ} \mathrm{C}$ (C) and a magnified image of $700^{\circ} \mathrm{C}$ (D). 
A

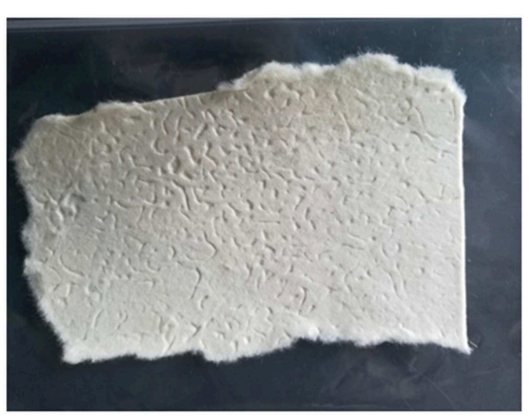

C

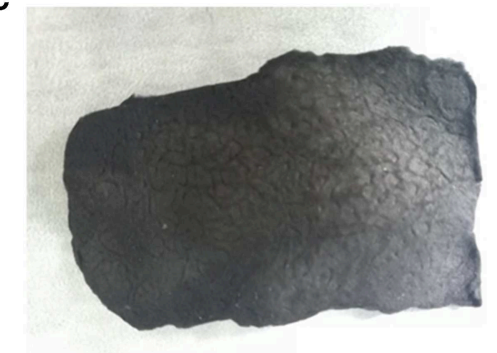

B

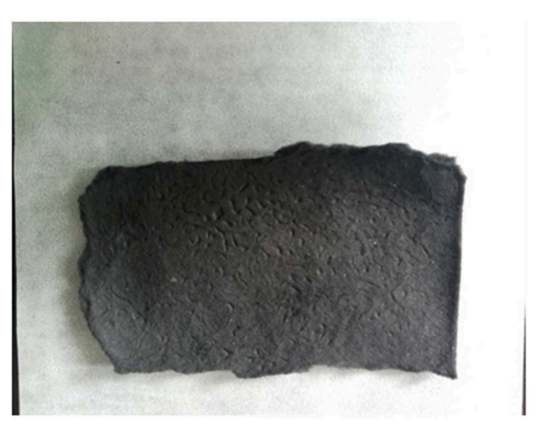

D

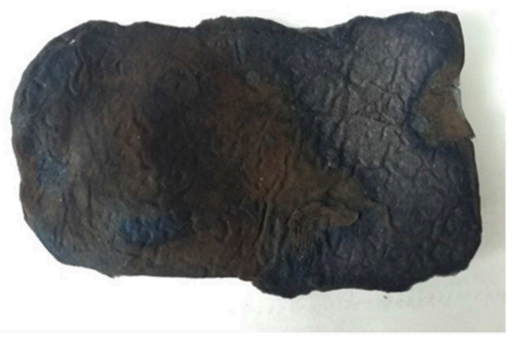

FIGURE 5 | Photographs showing the sisal hemp pulp-based paper before carbonization (A), after carbonization (B), after activation (C), and after $\mathrm{MnO}_{2}$ loading (D).

further activated. For activation, the procedure was the same as for the carbonization. However, when the temperature of activation had risen to $700^{\circ} \mathrm{C}$, the holding time was increased to $2 \mathrm{~h}$ to improve activation efficiency (Aber et al., 2009). In this part, $\mathrm{KOH}$ solution was used as the activator, with various concentrations investigated: $0.5,1.0,2.0,4.0,6.0$, and $8.0 \mathrm{~mol} / \mathrm{L}$. In the SEM images in Figures $6 \mathrm{~A}-\mathbf{F}$, it can be seen that with an increase in the activator concentration, the fiber structure was gradually destroyed, which was not conducive to adsorption performance. Generally speaking, a large specific surface area would be beneficial to the catalytic activity of the sample on account of providing more active sites ( $\mathrm{Li}$ et al., 2014). In addition, $\mathrm{N}_{2}$ adsorption-desorption measurements at $77 \mathrm{~K}$ were performed to obtain the specific surface area, pore volume, and pore size distribution, which are shown in Figures 6G,H; the detailed data is displayed in Table 4. As the concentration of the $\mathrm{KOH}$ solution increased, the total volume and micropore specific surface areas first increased and then decreased, reaching their maximum values at $1 \mathrm{~mol} / \mathrm{L}$. The corresponding micropore area and volume were $842.11 \mathrm{~m}^{2} / \mathrm{g}$ and $0.299 \mathrm{~cm}^{3} / \mathrm{g}$. Micropores accounted for $91.0 \%$ of the specific surface area and $84.2 \%$ of the pore volume. This was attributed to the fact that a low-concentration $\mathrm{KOH}$ solution could not fully activate the carbon fiber. With increasing $\mathrm{KOH}$ concentration, the carbon fiber could attain a higher level of activation. However, an excessive amount of $\mathrm{KOH}$ caused serious damage to the fiber structure and the collapse of micropores, leading to a decrease in micropore area and specific surface area (Aber et al., 2009). Therefore, a $\mathrm{KOH}$ solution of $1 \mathrm{~mol} / \mathrm{L}$ was suitable as the activator.
According to the results for carbonization and activation, the specific carbonization and activation procedures of preparing LACFP were as follows: a heating rate of $10^{\circ} \mathrm{C} / \mathrm{min}$ from ambient temperature to $280^{\circ} \mathrm{C}$, then at $2^{\circ} \mathrm{C} / \mathrm{min}$ from 280 to $400^{\circ} \mathrm{C}$, a holding time of $1 \mathrm{~h}$ at $400^{\circ} \mathrm{C}$, and heating at $15^{\circ} \mathrm{C} / \mathrm{min}$ from 400 to $700^{\circ} \mathrm{C}$ for the carbonization process, and a heating rate of $10^{\circ} \mathrm{C} / \mathrm{min}$ from ambient temperature to $280^{\circ} \mathrm{C}$, then $2^{\circ} \mathrm{C} / \mathrm{min}$ from 280 to $400^{\circ} \mathrm{C}$, a holding time of $1 \mathrm{~h}$ at $400^{\circ} \mathrm{C}$, heating at $15^{\circ} \mathrm{C} / \mathrm{min}$ from 400 to $700^{\circ} \mathrm{C}$, and a holding time of $2 \mathrm{~h}$ at $700^{\circ} \mathrm{C}$ for the activation process. The concentration of $\mathrm{KOH}$ for activation was $1 \mathrm{~mol} / \mathrm{L}$. The LACFP was prepared successively according to the above procedure (Figure 5C). The prepared LACFP was then used as the carrier for $\mathrm{MnO}_{2}$ loading. Table 5 shows the physical parameters of the sisal hemp paper before and after carbonization and after activation. It was found that sisal hemp pulp-based paper had high values of thickness, density, and softness. After carbonization or activation, the corresponding values were decreased to a great extent, which could be due to the mass loss of cellulose, hemicellulose, and lignin during the carbonization process and the formation of holes during the activation process. It is notable that the smaller the softness value, the softer the sample. Thus, the $\mathrm{MnO}_{2}$-loaded LACFP had a certain softness performance and was light, indicative of easy processing. Thus, LACFP could be applied as the filtration material of masks in the future.

\section{Characterization Analysis of LACFP and $\mathrm{MnO}_{2}$-Loaded LACFP}

The LACFP retained its integrity after loading with $\mathrm{MnO}_{2}$, as shown in Figure 5D. Furthermore, its values of thickness, 

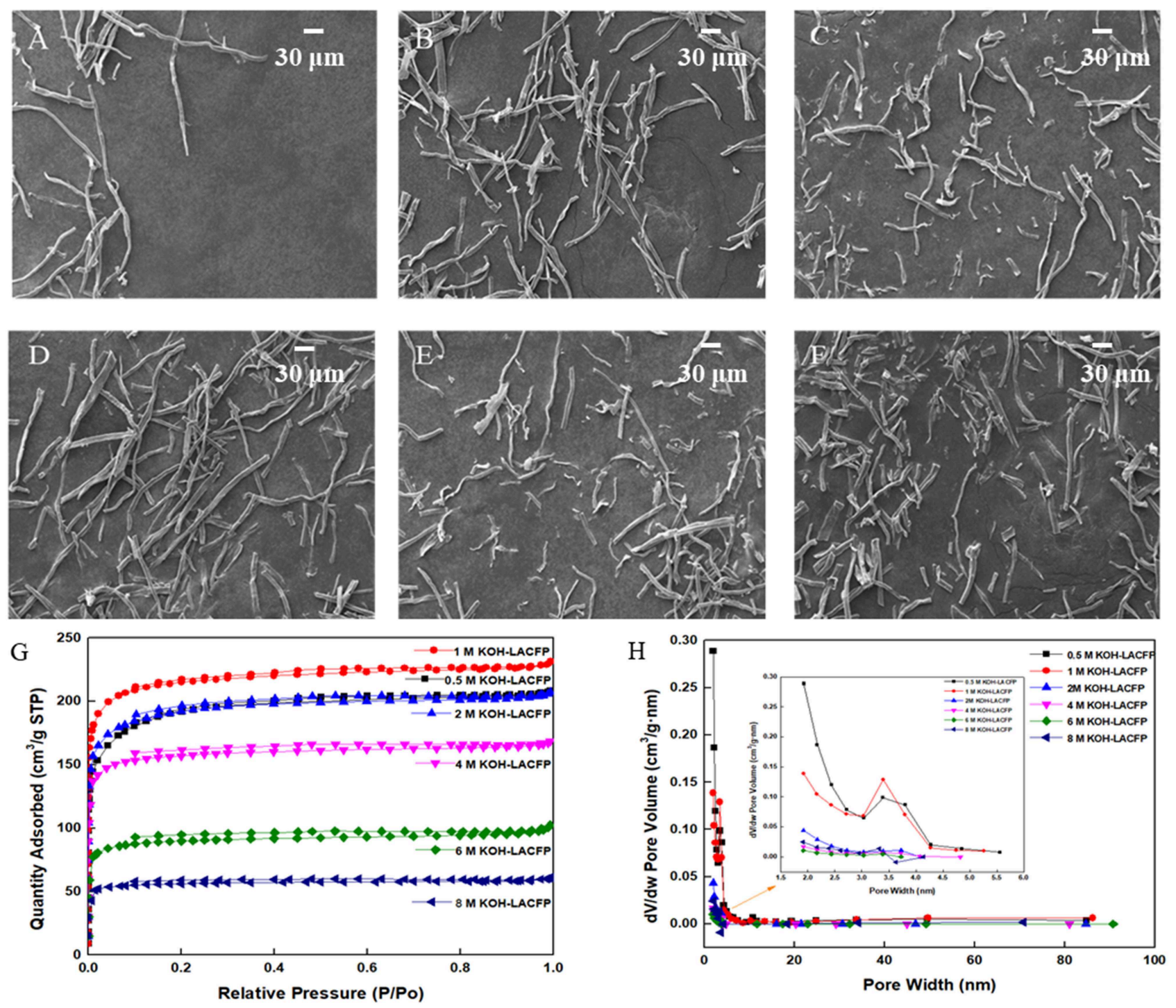

FIGURE 6 | SEM images of LACFP of KOH concentrations at (A) 0.5, (B) 1, (C) 2, (D) 4, (E) 6, and (F) 8 mol/L and their $\mathrm{N}_{2}$ adsorption-desorption isotherms (G) and pore size distribution curves $\mathbf{( H )}$

TABLE 4 | BET results for LACFP using different $\mathrm{KOH}$ concentrations.

\begin{tabular}{|c|c|c|c|c|c|}
\hline $\begin{array}{l}\mathrm{KOH} \\
\text { concentration } \\
\text { (mol/L) }\end{array}$ & $\begin{array}{l}S_{\text {BET }} \\
\left(\mathrm{m}^{2} / g\right)\end{array}$ & $\begin{array}{c}\text { Micropore } \\
\text { area } \\
\left(\mathrm{m}^{2} / \mathrm{g}\right)\end{array}$ & $\begin{array}{c}\text { Total } \\
\text { volume } \\
\left(\mathrm{cm}^{3} / \mathrm{g}\right)\end{array}$ & $\begin{array}{l}\text { Micropore } \\
\text { volume } \\
\left(\mathrm{cm}^{3} / \mathrm{g}\right)\end{array}$ & $\begin{array}{c}D_{p} \\
(n m)\end{array}$ \\
\hline 0.5 & 721 & 690 & 0.321 & 0.290 & 2.74 \\
\hline 1 & 842 & 766 & 0.355 & 0.299 & 3.19 \\
\hline 2 & 735 & 595 & 0.319 & 0.235 & 2.72 \\
\hline 4 & 625 & 565 & 0.259 & 0.216 & 3.04 \\
\hline 6 & 350 & 317 & 0.156 & 0.124 & 4.27 \\
\hline 8 & 225 & 206 & 0.093 & 0.0790 & 3.43 \\
\hline
\end{tabular}

density, and softness increased due to the generation of $\mathrm{MnO}_{2}$ (Table 5). However, these values were still much lower than that of sisal hemp paper before carbonization. Figure 7A shows the
TABLE 5 | Physical parameters of sisal hemp paper before and after carbonization and after activation and $\mathrm{MnO}_{2}$ loading.

\begin{tabular}{lccc}
\hline Paper & $\begin{array}{c}\text { Thickness } \\
(\boldsymbol{\mu} \mathbf{m})\end{array}$ & $\begin{array}{c}\text { Density } \\
\left(\mathbf{g} / \mathbf{c m}^{-3}\right)\end{array}$ & $\begin{array}{c}\text { Softness } \\
(\mathbf{m N})\end{array}$ \\
\hline Before carbonization & 640 & 0.22 & 2,457 \\
After carbonization & 295 & 0.13 & 224 \\
After activation & 268 & 0.13 & 109 \\
After $\mathrm{MnO}_{2}$ loading & 366 & 0.19 & 255 \\
\hline
\end{tabular}

XRD patterns of LACFP and $\mathrm{MnO}_{2}$-loaded LACFP. The two broad peaks at 22.8 and 43 , corresponding to the (002) and (100) crystal planes of carbon, are typical diffraction peaks of disordered graphite (Wang et al., 2014; Huang et al., 2015). After LACFP was impregnated with $\mathrm{MnSO}_{4}$ and $\mathrm{KMnO}_{4}$, respectively, 

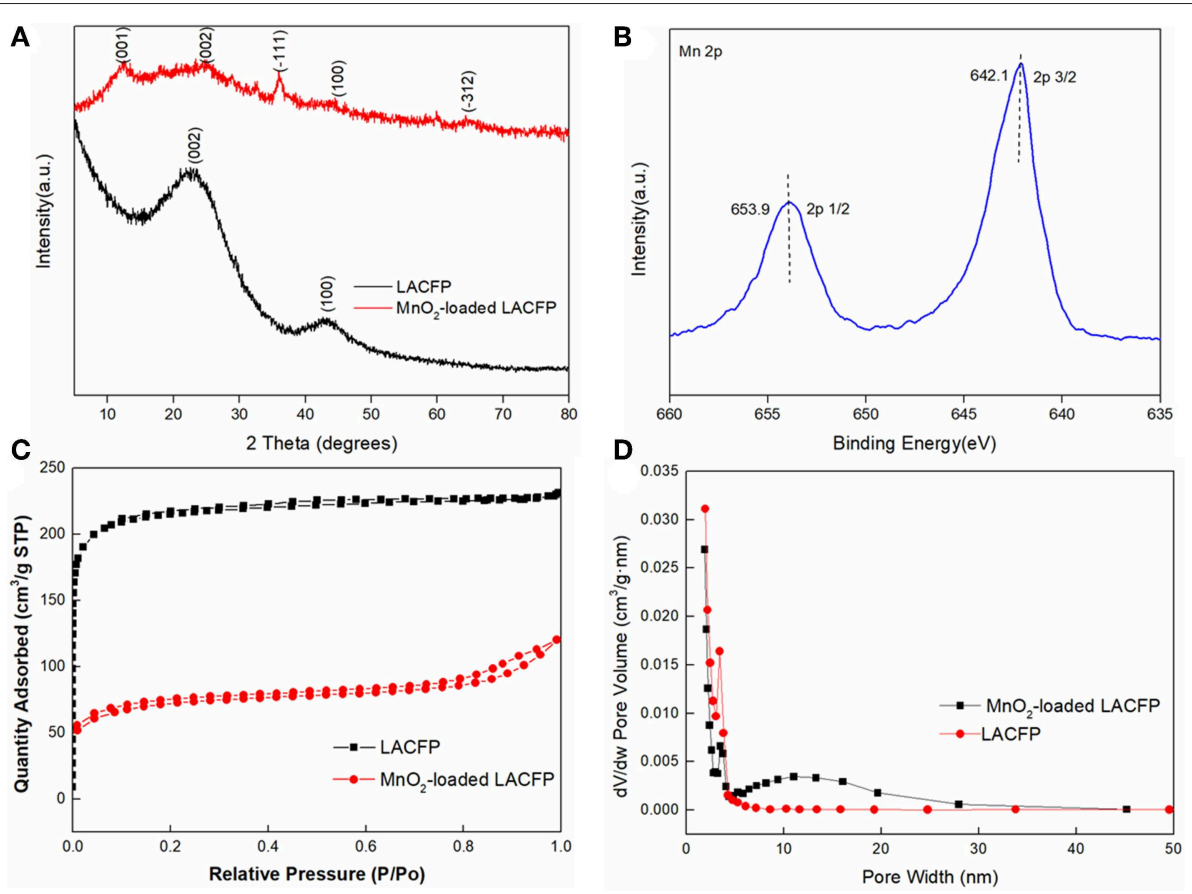

FIGURE 7 | Characterization of LACFP and $\mathrm{MnO}_{2}$-loaded LACFP [XRD patterns (A); Mn 2p XPS spectra (B); $\mathrm{N}_{2}$ adsorption-desorption isotherms obtained at $77 \mathrm{~K}$ (C); and size distribution (D)].

it generated different diffraction peaks at $12.1,24.5,36.1$, and 64.8 , which were ascribed to the (001), (002), (-111), and (020) crystal facets, respectively, and are characteristic peaks of $\delta$ $\mathrm{MnO}_{2}$ according to JCPDS 80-1098 (Zhang et al., 2015; Zou et al., 2019). Moreover, all the peaks of $\delta-\mathrm{MnO}_{2}$ in the composite are in accordance with those of pure $\mathrm{MnO}_{2}$. These results implied that $\mathrm{MnO}_{2}$ was successfully formed and loaded onto the LACFP.

Figure 8 illustrates the morphology of the LACFP and $\mathrm{MnO}_{2}$ loaded LACFP as shown by SEM, TEM, and HRTEM. Compared with the image of LACFP (Figure 6B), the surface of LACFP after $\mathrm{MnO}_{2}$ loading became rougher, and Figure 8A shows that the $\mathrm{MnO}_{2}$ catalyst was loaded on the surface of the LACFP evenly. As we can see from the image in Figure 8B, the lattice fringe in LACFP was unordered. However, after loading with $\mathrm{MnO}_{2}$, the TEM and HRTEM images in Figures 8C,D clearly show the existence of the lattice. The dark area may be $\mathrm{MnO}_{2}$, because its density is higher than that of carbon, which implies that $\mathrm{MnO}_{2}$ was embedded into the LACFP (Dong et al., 2006). The spacing between lattice stripes was $0.241 \mathrm{~nm}$, corresponding to the $\mathrm{MnO}_{2}(-111)$ crystal face. This result was consistent with the XRD analysis. The EDS pattern of $\mathrm{MnO}_{2}$-loaded LACFP and the contents of $\mathrm{C}, \mathrm{O}, \mathrm{Mg}, \mathrm{Si}, \mathrm{Cl}, \mathrm{K}, \mathrm{Ca}$, and $\mathrm{Mn}$ in the sample are displayed in Figure $\mathbf{S}$. The $\mathrm{Mg}, \mathrm{Cl}$, and Ca may come from tap water, which was used to disperse the sisal hemp pulp and form the paper sheet. Si and K may come from ash in the sisal hemp pulp and $\mathrm{KMnO}_{4}$, respectively. In general, the EDS spectrum of $\mathrm{MnO}_{2}$-loaded LACFP showed that the sample was mainly composed of the elements $\mathrm{C}, \mathrm{O}$, and $\mathrm{Mn}$. According to the content of $\mathrm{Mn}(8.00 \pm 0.07 \%)$, we calculated the loading amount of $\mathrm{MnO}_{2}$ in LACFP as $12.66 \pm 0.11 \%$.
XPS analysis was performed to investigate the surface electronic state of the $\mathrm{MnO}_{2}$-loaded LACFP. The spectra are showed in Figure 7B and exhibited two main peaks at 642.1 and $653.9 \mathrm{eV}$, belonging to $\mathrm{Mn} 2 \mathrm{p} 3 / 2$ and $\mathrm{Mn} 2 \mathrm{p} 1 / 2$, respectively. Their binding energy difference was $11.8 \mathrm{eV}$, and the spin-orbit splitting of Mn $2 \mathrm{p}$ is $11.7 \mathrm{eV}$. That indicated that it was close to the $\mathrm{MnO}_{2}$ structure $(642.2+11.7 \mathrm{eV}$ ) (Wang J. L. et al., 2017).

The $\mathrm{N}_{2}$ adsorption-desorption isotherms operating at $77 \mathrm{~K}$ for LACFP and $\mathrm{MnO}_{2}$-loaded LACFP are shown in Figures 7C,D. The pore size distribution of LACFP was mainly from 2 to $10 \mathrm{~nm}$, and its peak pore size was $3.39 \mathrm{~nm}$. However, the pore size distribution of $\mathrm{MnO}_{2}$-loaded LACFP was wider, from 2 to $45 \mathrm{~nm}$, and its peak pore size was $3.47 \mathrm{~nm}$. Moreover, the adsorption amount of $\mathrm{MnO}_{2}$-loaded LACFP considerably declined compared with that of LACFP. Previous studies reported that the pore diameter distribution of $\mathrm{MnO}_{2}$ was 11-14 $\mathrm{nm}$ (Zhang et al., 2015), whereas the pore diameter distribution of LACFP was 2-10 nm. Therefore, prepared $\mathrm{MnO}_{2}$ covered the surface and obstructed and destroyed the pores of LACFP (Wang et al., 2014). The specific surface area and pore volume of $\mathrm{MnO}_{2}$-loaded LACFP were $227.13 \mathrm{~m}^{2} / \mathrm{g}$ and 0.165 $\mathrm{cm}^{3} / \mathrm{g}$. The results indicate that $\mathrm{MnO}_{2}$ loading led to an increase in pore size and a decrease in specific surface area compared with LACFP.

\section{Catalytic Performance}

The catalytic performances of LACFP and the $\mathrm{MnO}_{2}$ loaded LACFP are evaluated in Figure 9. The differences in formaldehyde and $\Delta \mathrm{CO}_{2}$ were used to analyze the catalytic performance of these samples and are given in Table 6. For the 

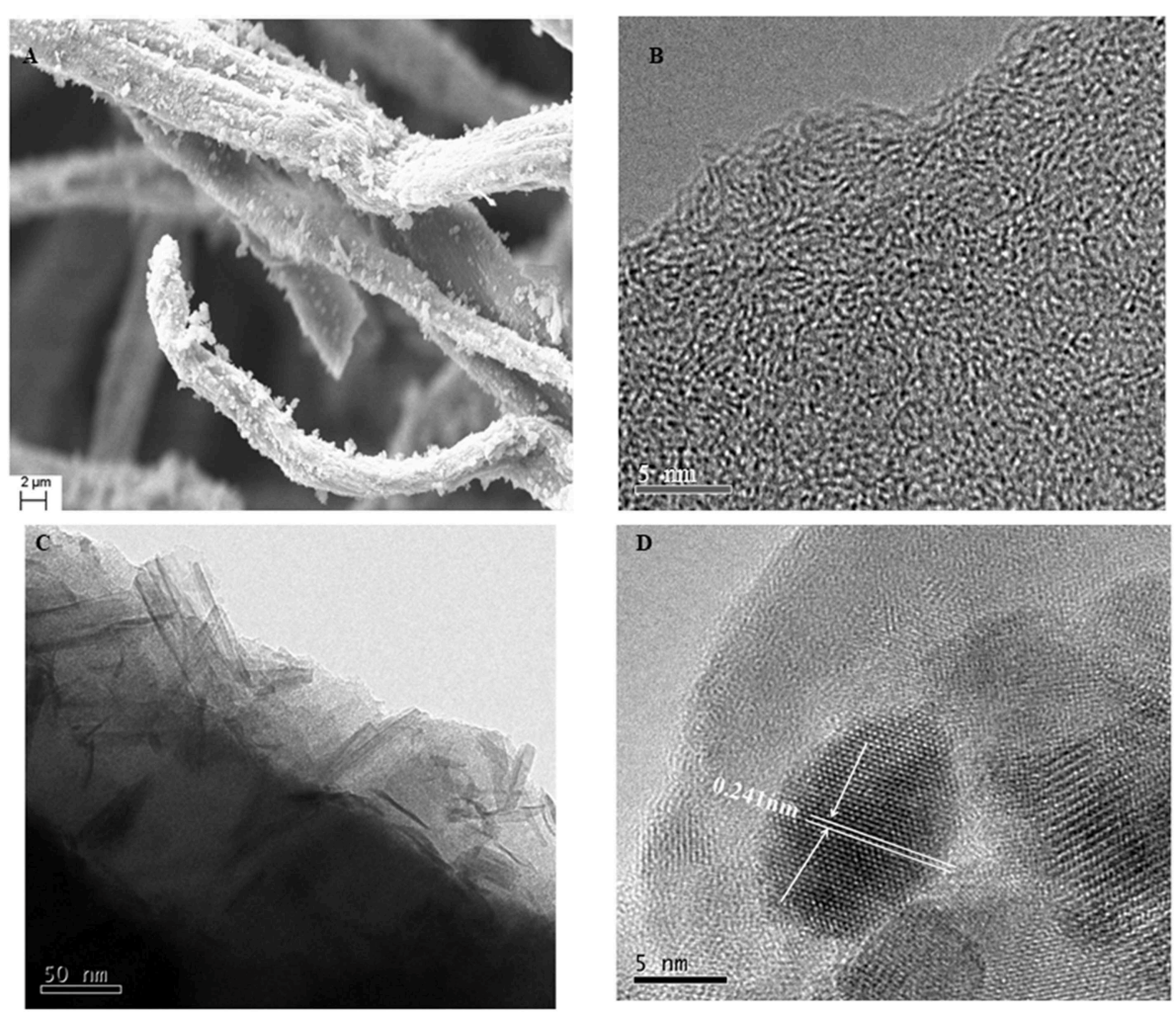

FIGURE 8 | The morphology of LACFP by HRTEM (B) and the morphology of $\mathrm{MnO}_{2}$-loaded LACFP by SEM (A), TEM (C), and HRTEM (D)
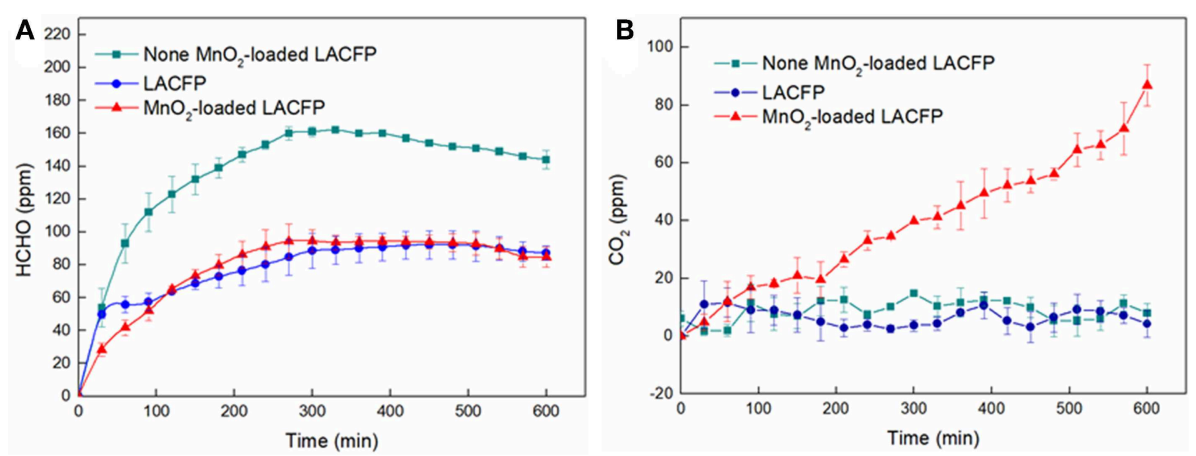

FIGURE 9 | Concentration variation of formaldehyde (A) and $\Delta \mathrm{CO}_{2}$ (B) for none ${ }^{\mathrm{a}}$, LACFP, and $\mathrm{MnO}_{2}$-loaded LACFP (aNone denotes only formaldehyde solution without other substances).

control sample, the concentration of formaldehyde increased from 0 to $161 \pm 5 \mathrm{ppm}$ in the initial $5 \mathrm{~h}$. However, the concentration of formaldehyde slightly decreased from $161 \pm 5$ to $144 \pm 2 \mathrm{ppm}$ in the second $5 \mathrm{~h}$. The concentration of $\Delta \mathrm{CO}_{2}$ was in a fluctuating state at 0 due to instrument accuracy effects. The reasons for the decrease in formaldehyde were that the concentration value of formaldehyde was highest after it was fully volatilized, and it took a long time for the formaldehyde to become distributed uniformly. For LACFP, the concentration of formaldehyde increased from 0 to $87 \pm 2.5 \mathrm{ppm}$ in the initial $5 \mathrm{~h}$ and tended toward stability in the second $5 \mathrm{~h}$, without emitting $\mathrm{CO}_{2}$, which implied that formaldehyde was only adsorbed by the LACFP. When the reaction was performed beyond $5 \mathrm{~h}$ for $\mathrm{MnO}_{2}$-loaded LACFP, the concentration of formaldehyde was nearly unchanged, which suggested that the adsorption for formaldehyde had halted due to saturation in $5 \mathrm{~h}$. In addition, the generation of $\mathrm{CO}_{2}$ was about $75 \pm 2 \mathrm{ppm}$ for $\mathrm{MnO}_{2}$-loaded LACFP, implying that the synergistic effect of LACFP and $\mathrm{MnO}_{2}$ led to the adsorption and catalysis of formaldehyde into $\mathrm{CO}_{2}$ and $\mathrm{H}_{2} \mathrm{O}$. Furthermore, the actual value of $\mathrm{CO}_{2}$ was 
TABLE 6 | The values of formaldehyde and $\Delta \mathrm{CO}_{2}$ over three different samples when the reaction was finished.

\begin{tabular}{lccc}
\hline Samples & $\begin{array}{c}\text { Formaldehyde } \\
(\mathbf{p p m})\end{array}$ & $\begin{array}{c}\mathbf{\Delta} \mathbf{C O}_{2} \\
(\mathbf{p p m})\end{array}$ & $\begin{array}{c}\text { Decreased } \\
\text { formaldehyde } \\
\text { (ppm) }\end{array}$ \\
\hline None & $144 \pm 2$ & 0 & - \\
LACFP & $87 \pm 3$ & 0 & $56 \pm 3$ \\
$\mathrm{MnO}_{2}$-loaded LACFP & $85 \pm 5$ & $75 \pm 3$ & $59 \pm 6$ \\
\hline
\end{tabular}

a little higher than the theoretical value due to the release of adsorbed formaldehyde in the inner wall and oxidization of formaldehyde into $\mathrm{CO}_{2}$, as well as the accuracy of the detector (Yan Z. et al., 2018).

The previous study indicated that the degradation mechanism of formaldehyde can be summarized as an adsorptiondegradation-desorption process (Zhou et al., 2011). Is has also been noted that the removal of formaldehyde can include adsorption and oxidation processes (Yan Z. et al., 2018). In the first $3 \mathrm{~h}$ of the reaction, adsorption played an important role during the formaldehyde removal process, accompanied by a large amount of formaldehyde adsorption and a small amount of $\mathrm{CO}_{2}$ generation. After that, adsorbed formaldehyde quickly began to be oxidized by surface active oxygen into dioctyl maleate (DOM), formate, carbonate, and $\mathrm{CO}_{2}$, resulting in a fast decline in the formaldehyde concentration on the sample and large amounts of $\mathrm{CO}_{2}$ generation, which indicated that formaldehyde was completely decomposed into $\mathrm{CO}_{2}$ (Wang J. L. et al., 2017; Yan Z. et al., 2018; Yan et al., 2019). Besides, the $\mathrm{MnO}_{2}$ catalyst can have various crystal structures, namely $\alpha, \beta, \gamma, \lambda$, and $\delta$ structures, which also affect the catalytic activity of $\mathrm{MnO}_{2}$ for the oxidation of formaldehyde (Devaraj and Munichandraiah, 2008). Of the $\alpha, \beta, \gamma$, and $\delta$ structures, $\delta-\mathrm{MnO}_{2}$ enhanced the catalytic oxidation of formaldehyde due to its 2D layered structure (Zhang et al., 2015; Wang J. L. et al., 2017). The prepared $\mathrm{MnO}_{2}$ on the LACFP was also proved to have the $\delta$ structure by XRD analysis. In general, LACFP played the role of adsorbent and carrier, and $\mathrm{MnO}_{2}$ provided catalytic sites for catalysis of formaldehyde. $\mathrm{MnO}_{2}$-loaded LACFP was thus a kind of portable and catalytic paper that has cost-effective and efficient feasibility for application in the field of the environmental treatment.

\section{CONCLUSIONS}

Sisal hemp pulp-based activated carbon fiber paper loaded with $\mathrm{MnO}_{2}$ was successfully prepared for the adsorption and in-situ catalytic degradation of formaldehyde into $\mathrm{CO}_{2}$ and $\mathrm{H}_{2} \mathrm{O}$. During the carbonization procedure, the heating rate and temperature were important factors controlling the damage level of fibers. In order to maintain the integrity of the fiber and paper

\section{REFERENCES}

Abdul Manap, N. R., Shamsudin, R., Maghpor, M. N., Abdul Hamid, M. A., and Jalar, A. (2018). Adsorption isotherm and kinetic study of gas-solid system of shape, the carbonization conditions were optimized. It was found that in the decomposition temperature range corresponding to major mass loss, a low heating rate resulted in a low mass loss of sisal hemp pulp-based paper. The suitable carbonization conditions were heating at $10^{\circ} \mathrm{C} / \mathrm{min}$ from room temperature to $280^{\circ} \mathrm{C}$, then at $2^{\circ} \mathrm{C} / \mathrm{min}$ from 280 to $400^{\circ} \mathrm{C}$, holding at $400^{\circ} \mathrm{C}$ for $1 \mathrm{~h}$, and then heating at $15^{\circ} \mathrm{C} / \mathrm{min}$ from 400 to $700^{\circ} \mathrm{C}$. The conditions of activation were almost the same as for carbonization, except that there was additional holding at $700^{\circ} \mathrm{C}$ for $2 \mathrm{~h}$. After loading with $\mathrm{MnO}_{2}$ using in situ synthesis, the LACFP still retained its shape integrity and some flexibility. $\mathrm{MnO}_{2}$-loaded LACFP displayed excellent catalytic performance for formaldehyde. The concentration of formaldehyde decreased by $59 \pm 6 \mathrm{ppm}$ and the concentration of $\Delta \mathrm{CO}_{2}$ increased by 75 $\pm 3 \mathrm{ppm}$ when the reaction proceeded at room temperature for $10 \mathrm{~h} . \mathrm{MnO}_{2}$-loaded LACFP has potential for application in toxic gas treatment.

\section{DATA AVAILABILITY STATEMENT}

The raw data supporting the conclusions of this article will be made available by the authors, without undue reservation, to any qualified researcher.

\section{AUTHOR CONTRIBUTIONS}

$\mathrm{XZ}$ and $\mathrm{BC}$ designed and carried out the preparation and characterization analysis of LACFP and wrote the research paper. QL and XL carried out the characterization and analysis of catalytic performance of $\mathrm{MnO}_{2}$-loaded LACFP and wrote the research paper. JR, CZ, and FP supervised the project, helped design the experiments, evaluated the data, and wrote the manuscript. The results of the manuscript were discussed by all authors.

\section{FUNDING}

This work was supported by the Program for National Natural Science Foundation of China (No. 21978104), Natural Science Foundation of Guangdong Province (No. 2019A1515011654), Guangdong Program for Support of Top-notch Young Professionals (No. 2016TQ03Z585), and Fundamental Research Funds for the Central Universities of SCUT, China (Nos. 2019PY17 and 2019PY13).

\section{SUPPLEMENTARY MATERIAL}

The Supplementary Material for this article can be found online at: https://www.frontiersin.org/articles/10.3389/fchem. 2019.00808/full\#supplementary-material

formaldehyde on oil palm mesocarp bio-char: pyrolysis effect. J. Environ. Chem. Eng. 6, 970-983. doi: 10.1016/j.jece.2017.12.067

Aber, S., Khataee, A., and Sheydaei, M. (2009). Optimization of activated carbon fiber preparation from Kenaf using $\mathrm{K}_{2} \mathrm{HPO}_{4}$ as chemical activator 
for adsorption of phenolic compounds. Bioresour. Technol. 100, 6586-6591. doi: 10.1016/j.biortech.2009.07.074

An, H., Feng, B., and Su, S. (2009). $\mathrm{CO}_{2}$ capture capacities of activated carbon fibre-phenolic resin composites. Carbon 47, 2396-2405. doi: 10.1016/j.carbon.2009.04.029

Arias, M. E., Polvillo, O., Rodriguez, J., Hernandez, M., Gonzalez-Perez, J. A., and Gonzalez-Vila, F. J. (2006). Thermal transformations of pine wood components under pyrolysis/gas chromatography/mass spectrometry conditions. J. Anal. Appl. Pyrolysis 77, 63-67. doi: 10.1016/j.jaap.2005.12.013

Boonamnuayvitaya, V., Sae-ung, S., and Tanthapanichakoon, W. (2005). Preparation of activated carbons from coffee residue for the adsorption of formaldehyde. Sep. Purif. Technol. 42, 159-168. doi: 10.1016/j.seppur.2004.07.007

Chen, W. H., Wang, C. W., Ong, H. C., Show, P. L., and Hsieh, T. H. (2019). Torrefaction, pyrolysis and two-stage thermodegradation of hemicellulose, cellulose and lignin. Fuel 258:116168. doi: 10.1016/j.fuel.2019. 116168

Cheng, B., Zhang, X., Lin, Q., Xin, F., Sun, R., Wang, X., et al. (2018). A new approach to recycle oxalic acid during lignocellulose pretreatment for xylose production. Biotechnol. Biofuels 11:324. doi: 10.1186/s13068-018-1325-3

Cui, W., Yuan, X., Wu, P., Zheng, B., Zhang, W., and Jia, M. (2015). Catalytic properties of $\gamma-\mathrm{Al}_{2} \mathrm{O}_{3}$ supported Pt-FeOx catalysts for complete oxidation of formaldehyde at ambient temperature. RSC Adv. 5, 104330-104336. doi: 10.1039/C5RA19151C

Dai, Z. J., Yu, X. W., Huang, C., Li, M., Su, J. F., Guo, Y. P., et al. (2016). Nanocrystalline $\mathrm{MnO}_{2}$ on an activated carbon fiber for catalytic formaldehyde removal. RSC Adv. 6, 97022-97029. doi: 10.1039/C6RA15463H

Deng, A. J., Ren, J. L., Wang, W. J., Li, H. L., Lin, Q. X., Yan, Y. H., et al. (2016). Production of xylo-sugars from corncob by oxalic acid-assisted ball milling and microwave-induced hydrothermal treatments. Ind. Crops Prod. 79, 137-145. doi: $10.1016 /$ j.indcrop.2015.11.032

Devaraj, S., and Munichandraiah, N. (2008). Effect of crystallographic structure of $\mathrm{MnO} 2$ on its electrochemical capacitance properties. J. Phys. Chem. C 112, 4406-4417. doi: 10.1021/jp7108785

Dong, X. P., Shen, W. H., Gu, J. L., Xiong, L. M., Zhu, Y. F., Li, H., et al. (2006). A structure of $\mathrm{MnO} 2$ embedded in CMK-3 framework developed by a redox method. Microporous Mesoporous Mater. 91, 120-127. doi: 10.1016/j.micromeso.2005.11.019

Dou, H., Long, D., Rao, X., Zhang, Y., Qin, Y., Pan, F., et al. (2019). Photocatalytic degradation kinetics of gaseous formaldehyde flow using $\mathrm{TiO}_{2}$ nanowires. ACS Sustain. Chem. Eng. 7, 4456-4465. doi: 10.1021/acssuschemeng.8b06463

Gopinath, A., and Kadirvelu, K. (2018). Strategies to design modified activated carbon fibers for the decontamination of water and air. Environ. Chem. Lett. 16, 1137-1168. doi: 10.1007/s10311-018-0740-9

Hong, X., Sun, Y., Zhu, T., and Liu, Z. (2016). Pt- $\mathrm{Au} / \mathrm{CeO}_{2}$ catalysts for the simultaneous removal of carbon monoxide and formaldehyde. Catal. Sci. Technol. 6, 3606-3615. doi: 10.1039/C5CY01744K

Huang, H., and Leung, D. Y. C. (2011). Complete oxidation of formaldehyde at room temperature using $\mathrm{TiO}_{2}$ supported metallic Pd nanoparticles. ACS Catal. 1, 348-354. doi: 10.1021/cs200023p

Huang, Y., Ma, E., and Zhao, G. (2015). Thermal and structure analysis on reaction mechanisms during the preparation of activated carbon fibers by $\mathrm{KOH}$ activation from liquefied wood-based fibers. Ind. Crops Prod. 69, 447-455. doi: 10.1016/j.indcrop.2015.03.002

Ishak, M. R., Sapuan, S. M., Leman, Z., Rahman, M. Z. A., and Anwar, U. M. K. (2011). Characterization of sugar palm (Arenga pinnata) fibres. J. Therm. Anal. Calorim. 109, 981-989. doi: 10.1007/s10973-011-1785-1

Jin, Z., Li, P., Liu, G., Zheng, B., Yuan, H., and Xiao, D. (2013). Enhancing catalytic formaldehyde oxidation on $\mathrm{CuO}-\mathrm{Ag}_{2} \mathrm{O}$ nanowires for gas sensing and hydrogen evolution. J. Mater. Chem. A. 1, 14736-14743. doi: $10.1039 / \mathrm{c} 3$ ta13277c

Kumagai, S., Sasaki, K., Shimizu, Y., and Takeda, K. (2008). Formaldehyde and acetaldehyde adsorption properties of heat-treated rice husks. Sep. Purif. Technol. 61, 398-403. doi: 10.1016/j.seppur.2007.12.006

Lee, K. J., Miyawaki, J., Shiratori, N., Yoon, S. H., and Jang, J. (2013). Toward an effective adsorbent for polar pollutants: formaldehyde adsorption by activated carbon. J. Hazard. Mater. 260, 82-88. doi: 10.1016/j.jhazmat.2013.04.049
Li, Y., Zhang, H., Wang, Y., Liu, P., Yang, H., Yao, X., et al. (2014). A selfsponsored doping approach for controllable synthesis of $\mathrm{S}$ and $\mathrm{N}$ co-doped trimodal-porous structured graphitic carbon electrocatalysts. Energy Environ. Sci. 7, 3720-3726. doi: 10.1039/C4EE01779J

Liang, J. J., Chen, J., Wu, S. B., Liu, C., and Lei, M. (2018). Comprehensive insights into cellulose structure evolution via multi-perspective analysis during a slow pyrolysis process. Sustain. Energy Fuels 2, 1855-1862. doi: 10.1039/C8SE00166A

Liu, P., Wei, G., He, H., Liang, X., Chen, H., Xi, Y., et al. (2019). The catalytic oxidation of formaldehyde over palygorskite-supported copper and manganese oxides: catalytic deactivation and regeneration. Appl. Surf. Sci. 464, 287-293. doi: 10.1016/j.apsusc.2018.09.070

Lo, T. H., Tsay, Y. S., Chiang, C. L., and Lee, C. Y. (2015). Experimental evaluation of indoor formaldehyde decomposition performance of atmospheric plasma reactor utilizing sensor network. Int. J. Distrib. Sens. Netw. 11:761439. doi: $10.1155 / 2015 / 761439$

Lu, S., Chen, C., Wang, X., Wei, S., Zhu, Q., Huang, F., et al. (2018). Efficient catalytic removal of formaldehyde over $\mathrm{Ag} / \mathrm{Co}_{3} \mathrm{O}_{4}-\mathrm{CeO}_{2}$ prepared by different method. Catal. Surv. Asia 22, 63-71. doi: 10.1007/s10563-018-9240-y

Ma, C., Pang, G., He, G., Li, Y., He, C., and Hao, Z. (2016). Layered sphere-shaped $\mathrm{TiO} 2$ capped with gold nanoparticles on structural defects and their catalysis of formaldehyde oxidation. J. Environ. Sci. 39, 77-85. doi: 10.1016/j.jes.2015.12.004

Nie, L., Yu, J., Jaroniec, M., and Tao, F. F. (2016). Room-temperature catalytic oxidation of formaldehyde on catalysts. Catal. Sci. Technol. 6, 3649-3669. doi: 10.1039/C6CY00062B

Pan, W., Ma, Z., Liu, J., Liu, Q., and Wang, J. (2011). Effect of heating rate on morphology and structure of $\mathrm{CoFe}_{2} \mathrm{O}_{4}$ nanofibers. Mater. Lett. 65, 3269-3271. doi: 10.1016/j.matlet.2011.06.102

Pei, J., Han, X., and Lu, Y. (2015). Performance and kinetics of catalytic oxidation of formaldehyde over copper manganese oxide catalyst. Build. Environ. 84, 134-141. doi: 10.1016/j.buildenv.2014.11.002

Peng, Y. Y., and Wu, S. B. (2010). The structural and thermal characteristics of wheat straw hemicellulose. J. Anal. Appl. Pyrolysis 88, 134-139. doi: 10.1016/j.jaap.2010.03.006

Puziy, A. M., Poddubnaya, O. I., and Sevastyanova, O. (2018). Carbon materials from technical lignins: recent advances. Top. Curr. Chem. 376:33. doi: 10.1007/s41061-018-0210-7

Rong, S., Zhang, P., Liu, F., and Yang, Y. (2018). Engineering crystal facet of $\alpha-$ $\mathrm{MnO}_{2}$ nanowire for highly efficient catalytic oxidation of carcinogenic airborne formaldehyde. ACS Catal. 8, 3435-3446. doi: 10.1021/acscatal.8b00456

Salthammer, T. (2013). Formaldehyde in the ambient atmosphere: from an indoor pollutant to an outdoor pollutant? Angew. Chem. Int. Ed. 52, 3320-3327. doi: 10.1002/anie.201205984

Sangmanee, M., and Maensiri, S. (2009). Nanostructures and magnetic properties of cobalt ferrite $\left(\mathrm{CoFe}_{2} \mathrm{O}_{4}\right)$ fabricated by electrospinning. Appl. Phys. A 97, 167-177. doi: 10.1007/s00339-009-5256-5

Saulich, K., and Müller, S. (2013). Removal of formaldehyde by adsorption and plasma treatment of mineral adsorbent. J. Phys. D Appl. Phys. 46:045201. doi: 10.1088/0022-3727/46/4/045201

Sun, S., Ding, J., Bao, J., Gao, C., Qi, Z., and Li, C. (2010). Photocatalytic oxidation of gaseous formaldehyde on $\mathrm{TiO}_{2}$ : an in situ drifts study. Catal. Lett. 137, 239-246. doi: 10.1007/s10562-010-0358-4

Tan, H., Wang, J., Yu, S., and Zhou, K. (2015). Support morphology-dependent catalytic activity of $\mathrm{Pd} / \mathrm{CeO}_{2}$ for formaldehyde oxidation. Environ. Sci. Technol. 49, 8675-8682. doi: 10.1021/acs.est.5b01264

Wang, J., Yunus, R., Li, J., Li, P., Zhang, P., and Kim, J. (2015). In situ synthesis of manganese oxides on polyester fiber for formaldehyde decomposition at room temperature. Appl. Surf. Sci. 357, 787-794. doi: 10.1016/j.apsusc.2015. 09.109

Wang, J. L., Li, J. E., Jiang, C. J., Zhou, P., Zhang, P. Y., and Yu, J. G. (2017). The effect of manganese vacancy in birnessite-type $\mathrm{MnO}_{2}$ on room-temperature oxidation of formaldehyde in air. Appl. Catal. B Environ. 204, 147-155. doi: 10.1016/j.apcatb.2016.11.036

Wang, L., Yue, H., Hua, Z., Wang, H., Li, X., and Li, L. (2017). Highly active Pt/Na $\mathrm{TiO}_{2}$ catalyst for low temperature formaldehyde decomposition. Appl. Catal. B Environ. 219, 301-313. doi: 10.1016/j.apcatb.2017.07.073 
Wang, M., Liu, H., Huang, Z. H., and Kang, F. (2014). Activated carbon fibers loaded with $\mathrm{MnO}_{2}$ for removing $\mathrm{NO}$ at room temperature. Chem. Eng. J. 256, 101-106. doi: 10.1016/j.cej.2014.06.108

Yan, Y., Zhang, C., Lin, Q., Wang, X., Cheng, B., Li, H., et al. (2018). Microwaveassisted oxalic acid pretreatment for the enhancing of enzyme hydrolysis in the production of xylose and arabinose from bagasse. Molecules 23:E862. doi: 10.3390/molecules23040862

Yan, Z., Xu, Z., Yang, Z., Yue, L., and Huang, L. (2019). Graphene oxide/ $/ \mathrm{Fe}_{2} \mathrm{O}_{3}$ nanoplates supported $\mathrm{Pt}$ for enhanced room-temperature oxidation of formaldehyde. Appl. Surf. Sci. 467, 277-285. doi: 10.1016/j.apsusc.2018.10.123

Yan, Z., Yang, Z., Xu, Z., An, L., Xie, F., and Liu, J. (2018). Enhanced room-temperature catalytic decomposition of formaldehyde on magnesiumaluminum hydrotalcite/boehmite supported platinum nanoparticles catalyst. J. Colloid Interface Sci. 524, 306-312. doi: 10.1016/j.jcis.2018.04.018

Yang, H., Yan, R., Chen, H., Lee, D. H., and Zheng, C. (2007). Characteristics of hemicellulose, cellulose and lignin pyrolysis. Fuel 86, 1781-1788. doi: 10.1016/j.fuel.2006.12.013

Zeng, L., Song, W., Li, M., Zeng, D., and Xie, C. (2014). Catalytic oxidation of formaldehyde on surface of $\mathrm{H}-\mathrm{TiO}{ }_{2} / \mathrm{H}-\mathrm{C}-\mathrm{TiO}_{2}$ without light illumination at room temperature. Appl. Catal. B Environ. 147, 490-498. doi: 10.1016/j.apcatb.2013.09.013

Zhang, J., Li, Y., Wang, L., Zhang, C., and He, H. (2015). Catalytic oxidation of formaldehyde over manganese oxides with different crystal structures. Catal. Sci. Technol. 5, 2305-2313. doi: 10.1039/C4CY01461H
Zhou, L., He, J., Zhang, J., He, Z., Hu, Y., Zhang, C., et al. (2011). Facile InSitu synthesis of manganese dioxide nanosheets on cellulose fibers and their application in oxidative decomposition of formaldehyde. J. Phys. Chem. C 115, 16873-16878. doi: 10.1021/jp2050564

Zhu, T., Zhang, X., Han, Y., Liu, T., Wang, B., and Zhang, Z. (2019). Preparation of zeolite $\mathrm{X}$ by the aluminum residue from coal fly ash for the adsorption of volatile organic compounds. Front. Chem. 7:341. doi: 10.3389/fchem.2019.00341

Zou, N., Nie, Q., Zhang, X., Zhang, G., Wang, J., and Zhang, P. (2019) Electrothermal regeneration by Joule heat effect on carbon cloth based $\mathrm{MnO}_{2}$ catalyst for long-term formaldehyde removal. Chem. Eng. J. 357, 1-10. doi: 10.1016/j.cej.2018.09.117

Conflict of Interest: The authors declare that the research was conducted in the absence of any commercial or financial relationships that could be construed as a potential conflict of interest.

Copyright (c) 2019 Zhang, Zhang, Lin, Cheng, Liu, Peng and Ren. This is an openaccess article distributed under the terms of the Creative Commons Attribution License (CC BY). The use, distribution or reproduction in other forums is permitted, provided the original author(s) and the copyright owner(s) are credited and that the original publication in this journal is cited, in accordance with accepted academic practice. No use, distribution or reproduction is permitted which does not comply with these terms. 